\title{
CORRIGENDUM
}

Genes \& Development 35: 59-64 (2021)

\section{Corrigendum: mTOR inhibition acts as an unexpected checkpoint in p53-mediated tumor suppression}

Ning Kon, Yang Ou, Shang-Jui Wang, Huan Li, Anil K. Rustgi, and Wei Gu

In the print edition of the above-mentioned article, there were errors in panels 1, 5, 9, and 13 in Figure 1B. These errors have been corrected in the article online.

doi: $10.1101 / \operatorname{gad} .348236 .121$ 


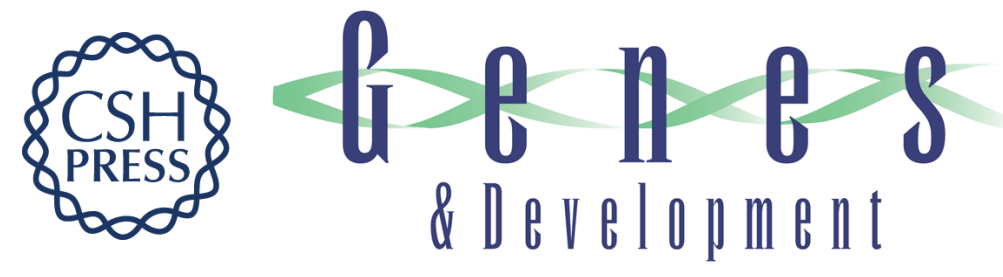

\section{Corrigendum: mTOR inhibition acts as an unexpected checkpoint in p53-mediated tumor suppression}

Ning Kon, Yang Ou, Shang-Jui Wang, et al.

Genes Dev. 2021, 35:

Access the most recent version at doi:10.1101/gad.348236.121
Related Content mTOR inhibition acts as an unexpected checkpoint in p53-mediated tumor suppression
Ning Kon, Yang Ou, Shang-Jui Wang, et al.
Genes Dev. January, 2021 35: 59-64

\section{License}

Email Alerting

Receive free email alerts when new articles cite this article - sign up in the box at the top

Service 